\title{
Analisis Deskriptif dan Tabulasi Silang pada Konsumen Online shop di Instagram (Studi Kasus 6 Universitas di Kota Surabaya)
}

\author{
Bella Harum Ashari, Berto Mulia Wibawa dan Satria Fadil Persada \\ Jurusan Manajemen Bisnis, Fakultas Teknologi Industri, Institut Teknologi Sepuluh Nopember (ITS) \\ Jl. Arief Rahman Hakim, Surabaya 60111, Indonesia \\ e-mail: berto@mb.its.ac.id
}

\begin{abstract}
Abstrak-Perkembangan pengguna situs jejaring sosial di Indonesia telah memunculkan suatu paradigma $e$-commerce baru yang disebut social commerce (s-commerce). Salah satu media scommerce yang digunakan untuk memfasilitasi jual beli produk adalah Instagram. Permasalahan yang menjadi keterbatasan dalam belanja online adalah pemahaman peritel online terhadap karakteristik dari konsumen online shop di Instagram. Penelitian ini bertujuan untuk mengetahui karakteristik dari konsumen online shop di Instagram. Penelitian ini menggunakan metode analisis deskriptif dan analisis tabulasi silang terhadap 231 responden dari 6 Universitas di Kota Surabaya yang pernah berbelanja di online shop di Instagram. Hasil yang didapat dari penelitian ini adalah konsumen yang berupa mahasiswi cenderung memiliki pengeluaran untuk belanja online per bulan dibawah Rp. 300.000, dan mayoritas repsonden mengutamakan faktor harga produk yang murah. Oleh karena itu peritel online harus memperhatikan faktor harga produk sehingga akan dapat memunculkan niat beli bagi konsumen.
\end{abstract}

Kata Kunci-Analisis Deskriptif, Analisis Tabulasi Silang, Instagram, S-Commerce.

\section{PENDAHULUAN}

$\mathrm{P}$ ERKEMBANGAN internet yang mempermudah komunikasi serta persebaran informasi bagi masyarakat Indonesia berdampak pada munculnya berbagai aktivitas virtual yang dilakukan oleh pengguna internet di Indonesia seperti berkirim e-mail, mencari informasi barang dan jasa, menerima pemesanan barang dan jasa, aktif media sosial dan melakukan pembelian barang dan jasa [1]. Pembelian barang dan jasa yang dilakukan tidak terbatas pada e-commerce saja, namun juga pada media sosial sehingga memunculkan suatu konsep e-commerce baru bernama social commerce (scommerce). S-commerce merupakan suatu perpaduan antara ecommerce dengan media sosial untuk memfasilitasi jual beli produk dan jasa dengan menggunakan teknologi internet [2]. Salah satu jejaring sosial yang populer digunakan sebagai media s-commerce adalah Instagram. Pengguna Instagram di Indonesia adalah sebanyak 80 juta pengguna, dimana $89 \%$ pengguna Instagram ada pada usia 18 hingga 35 tahun dan $63 \%$ diantaranya adalah wanita [3].

Berbagai online shop yang menjual bermacam-macam produk seperti apparel, kosmetik, aksesoris, dan elektronik menjadi pilihan bagi konsumen untuk dapat berbelanja online secara efisien [3]. Bisnis s-commerce di Instagram menjadi peluang bagi peritel online untuk dapat memperluas basis konsumen. Kunci bagi peritel online di Instagram untuk dapat terus berkembang adalah dengan menerapkan strategi yang tepat untuk menjalin hubungan jangka panjang dengan konsumen. Peritel online memiliki peluang untuk terus tumbuh dan berinovasi jika peritel online memahami karakteristik konsumen dari online shop di Instagram. Sehingga peritel online dapat menerapkan strategi yang tepat untuk dapat menimbulkan niat beli konsumen.

\section{URAIAN PENELITIAN}

\section{A. Online Retail}

Konsep ritel online berkembang selama beberapa tahun terakhir. Perkembangan ritel online telah diprediksi oleh analis pada tahun 1998 sebagai bentuk dari toko ritel yang memanfaatkan teknologi yang canggih yang akan menguasai industri ritel [4]. Ritel online merupakan suatu kegiatan ritel secara online, dengan memanfaatkan jaringan internet. Ritel online adalah format ritel dimana pengecer dan konsumen berkomunikasi dan bertransaksi satu sama lain dengan media jaringan elektronik secara interaktif [5]. Meskipun penjualan melalui ritel online berkembang lebih cepat daripada penjualan melalui toko dan katalog, namun konsumen menyadari bahwa internet bukan merupakan format baru yang revolusioner yang menggantikan toko dan katalog. Ritel online menawarkan kemudahan dalam berbelanja secara mudah dan efektif.

\section{B. E-commerce}

Electronic commerce atau dapat disebut sebagai e-commerce merupakan salah satu dari revolusi teknologi informasi dalam bidang ekonomi yang menghilangkan berbagai batasan dalam bisnis tradisional [6]. Value proposition yang ditawarkan oleh e-commerce adalah jual beli secara online atau kemampuan untuk bertransaksi secara online [7]. Keberadaan pasar virtual dalam bentuk e-commerce merupakan suatu kemudahan berbelanja dimana konsumen dapat memesan produk dengan transaksi pembayaran secara elektronik. Ritel dan perbankan online merupakan contoh dari e-commerce, dimana pembeli akan melakukan transaksi serta benar-benar melakukan pembelian. E-commerce dapat dilakukan oleh berbagai pihak, dimana digolongkan berdasarkan jenis transaksinya [8] yaitu B2C (business-to-consumer), B2B (business-to-business), C2C (consumer-to-consumer), $\mathrm{C} 2 \mathrm{~B} \quad$ (consumer-to-business), intraorganizational, G2C (government-to-citizen), mcommerce (mobile commerce) serta s-commerce (social commerce). 


\section{S-commerce}

Social commerce (s-commerce) merupakan bentuk bisnis online yang mengkombinasikan electronic commerce (ecommerce) dengan media sosial atau situs jejaring sosial untuk memberikan konsumen penawaran harian terkait produk dan jasa [2]. S-commerce merupakan konsep baru dalam bisnis online seiring dengan berkembangnya pasar e-commerce. Scommerce secara tidak langsung menawarkan suatu bisnis model baru pada retailer tradisional dengan mengintegrasikan bisnisnya dengan media sosial untuk meningkatkan performansi bisnis mereka. Disisi lain, s-commerce juga membuat konsumen merasakan pengalaman berbelanja baru pada online store di media sosial yang mereka gunakan. Ecommerce menggunakan media sosial dimana memfasilitasi interaksi sosial dan menambah pengalaman belanja online konsumen [9]. Melalui bisnis model s-commerce, peritel online dapat memberikan layanan pribadi secara lebih akurat, kemudahan dan monitoring sosial pada pelanggan mereka [10].

\section{Crosstabs}

Analisis tabulasi silang atau Crosstabs digunakan untuk menghitung frekuensi dan persentase dua atau lebih variabel secara sekaligus dengan cara menyilangkan variabel-variabel yang dianggap berhubungan sehingga makna hubungan dua .variabel mudah dipahami secara deskriptif [11]. Tujuan dari analisis ini adalah untuk mengidentifikasi korelasi antara satu variabel dengan variabel lainnya. Salah satu ciri-ciri dari penggunaan data crosstab adalah data input yang digunakan yaitu data nominal atau ordinal sehingga akan menghasilkan output yang dapat dijelaskan secara deskriptif [12].

\section{METODOLOGI PENELITIAN}

\section{A. Desain Penelitian}

Jenis penelitian yang akan dilaksanakan adalah penelitian conclusive, yaitu penelitian yang bertujuan untuk menguji hubungan antar variabel. Sifat dari penelitian ini adalah deskriptif, yang hasilnya menjelaskan mengenai karakteristik atau fungsi pasar yang berguna untuk membantu membuat keputusan dalam menentukan, mengevaluasi dan memilih alternatif tindakan terbaik dalam sebuah situasi [13]. Penelitian dilakukan dengan survey menggunakan multiple crosssectional, yang dilakukan pada satu periode terhadap berbagai sampel dalam populasi.

Data primer akan didapatkan melalui persebaran kuesioner yang disebar online dan offline dengan metode selfadministrated questionnaire. Pertanyaan pada kuesioner dibagi 3 yaitu mengenai demografi responden dan usage responden. Profil responden berisi mengenai informasi usia, asal universitas, uang saku, dan sumber pendapatan. Usage responden berisi mengenai beberapa pertanyaan terkait perilaku responden seperti lama aktif mengikuti online shop, jumlah online shop yang di follow, frekuensi berbelanja di online shop, produk yang paling sering dibeli, online shop favorit, pertimbangan dalam memfavoritkan online shop dan lain-lain.

\section{B. Sampel}

Metode sampling yang digunakan adalah non-probability sampling kategori judgemental sampling, yang memilih responden berdasarkan ciri khusus sampel yang dipandang memiliki karakteristik yang erat dengan ciri-ciri atau sifat populasi yang sudah diketahui sebelumnya [14]. Subjek dari penelitian ini adalah perempuan kisaran usia 17 hingga 24 tahun yang ITS, Universitas Airlangga, Universitas Negeri Surabaya, UIN Sunan Ampel, Universitas Tujuh Belas Agustus dan Universitas Hang Tuah Surabaya. Pemilihan subjek penelitian yang berupa mahasiswi dikarenakan mayoritas pengguna Instagram adalah perempuan dengan rentang usia 18 hingga 35 tahun, sehingga peneliti menfokuskan subjek penelitian pada mahasiswi yang masuk dalam rentang usia tersebut. Sampel dalam penelitian ini mengacu pada subjek penelitian, yaitu beberapa mahasiswi pada 6 universitas yang telah ditentukan.

\section{Metode Analisis Data}

Pengolahan data pada penelitian ini menggunakan metode analisis deskriptif dan analisis tabulasi silang. Analisis deskriptif bertujuan untuk mengubah sekumpulan data mentah menjadi bentuk yang lebih mudah dipahami yang berbentuk informasi yang lebih ringkas [15]. Analisis deskriptif dalam penelitian ini dilakukan pada hasil data responden berdasarkan profil, demografi serta usage. Metode deskriptif digunakan untuk mendeskripsikan atau menggambarkan data yang terkumpul tanpa bermaksud membuat kesimpulan yang berlaku untuk umum atau generalisasi [16]. Sedangkan analisis tabulasi silang pada penelitian ini akan dilakukan pada variabel demografi responden, yaitu asal universitas, uang saku, pengeluaran per bulan, pengeluaran belanja online per bulan, frekuensi belanja online, produk yang paling sering dibeli dan pertimbangan dalam memfavoritkan online shop dengan menggunakan metode tabulasi silang layer atau perkalian 3 variabel demografi dan usage.

\section{HASIL ANALISIS DATA DAN DISKUSI}

\section{A. Analisis Deskriptif Demografi}

Dari 231 data yang diperoleh selama 6 hari penyebaran kuesioner online dan offline di 6 Universitas di Kota Surabaya, didapat informasi bahwa $100 \%$ responden adalah perempuan dikarenakan batasan yang telah ditentukan dalam penelitian ini adalah responden berupa mahasiswi. Kategori umur didominasi oleh responden 21 tahun yaitu sebesar 39,4\%. Mayoritas responden berasal dari ITS yaitu sebesar $24,2 \%$ yang memiliki uang saku mayoritas sebesar kurang dari Rp.1.000.000 (46,6\%). Sebesar $71,4 \%$ persen responden tidak memiliki sumber pendapatan lain dan memiliki pengeluaran sebesar kurang dari Rp.1.000.000 (58,4\%). Untuk pengeluaran belanja online, mayoritas responden memiliki pengeluaran belanja online per bulan kurang dari Rp.300.000 (78,4\%).

$$
\text { Tabel } 1 .
$$

Demografi Responden

\begin{tabular}{lccc}
\hline \hline & Profil & Frekuensi & Persentase \% \\
\hline Gender & & & \\
Perempuan & & 231 & 100 \\
& Total & 231 & 100
\end{tabular}




\begin{tabular}{|c|c|c|}
\hline \multicolumn{3}{|l|}{ Usia } \\
\hline 17 th & 4 & 1,7 \\
\hline 18 th & 31 & 13,4 \\
\hline 19 th & 39 & 16,9 \\
\hline 20 th & 32 & 13,9 \\
\hline 21 th & 91 & 39,4 \\
\hline 22 th & 26 & 11,3 \\
\hline 23 th & 4 & 1,7 \\
\hline 24 th & 4 & 1,7 \\
\hline Total & 231 & 100 \\
\hline \multicolumn{3}{|l|}{ Asal Universitas } \\
\hline ITS & 56 & 24,2 \\
\hline UIN Sunan Ampel & 31 & 13,4 \\
\hline Univ. Airlangga & 40 & 17,3 \\
\hline Univ. Hang Tuah & 35 & 15,2 \\
\hline Univ. Negeri Surabaya & 34 & 14,7 \\
\hline Univ. Tujuh Belas Agustus & 35 & 15,2 \\
\hline Total & 231 & 100 \\
\hline \multicolumn{3}{|l|}{ Uang Saku per Bulan } \\
\hline$\leq$ Rp. 1.000 .000 & 110 & 47,6 \\
\hline Rp.1.000.0001 - Rp.1.500.000 & 83 & 35,9 \\
\hline Rp.1.500.001- Rp.2.000.000 & 20 & 8,7 \\
\hline$>\mathrm{Rp} .2 .000 .000$ & 18 & 7,8 \\
\hline Total & 231 & 100 \\
\hline \multicolumn{3}{|l|}{ Pendapatan Lain } \\
\hline Bisnis & 33 & 14,3 \\
\hline Investasi & 3 & 1,3 \\
\hline Kerja Sampingan & 26 & 11,3 \\
\hline Lainnya & 4 & 1,7 \\
\hline Tidak & 165 & 71,4 \\
\hline Total & 231 & 100 \\
\hline \multicolumn{3}{|l|}{ Pengeluaran per Bulan } \\
\hline$\leq \mathrm{Rp} .1 .000 .000$ & 135 & 58,4 \\
\hline Rp.1.000.0001 - Rp.1.500.000 & 66 & 28,6 \\
\hline Rp.1.500.001- Rp.2.000.000 & 22 & 9,5 \\
\hline$>$ Rp.2.000.000 & 8 & 3,5 \\
\hline Total & 231 & 100 \\
\hline \multicolumn{3}{|c|}{ Pengeluaran Belanja Online per Bulan } \\
\hline$\leq \mathrm{Rp} .300 .000$ & 181 & 78,4 \\
\hline Rp.300.0001 - Rp.600.000 & 42 & 18,2 \\
\hline Rp.600.001-Rp.1.000.000 & 6 & 2,6 \\
\hline$>$ Rp.1.000.000 & 2 & 0,9 \\
\hline Total & 231 & 100 \\
\hline
\end{tabular}

\section{B. Analisis Deskriptif Usage}

Selanjutnya adalah informasi responden berupa usage, dimana didapatkan informasi bahwa sebanyak $84,4 \%$ responden berbelanja di online shop sebanyak 1 hingga 3 kali dalam jangka waktu 3 bulan terakhir, dimana responden mempertimbangakn faktor harga sebagai faktor utama dalam memfavoritkan online shop $(37,2 \%)$.

Tabel 2.

Usage Responden

\begin{tabular}{ccc}
\hline \hline \multicolumn{1}{c}{ Profil } & Frekuensi & Persentase \% \\
\hline Aktif Instagram & & \\
< 1 tahun & 22 & 9,5 \\
1 - 2 tahun & 55 & 23,8 \\
2 - 4 tahun & 114 & 49,4 \\
> 4 tahun & 40 & 17,3 \\
Total & 231 & 100 \\
Aktif Follow Online shop di Instagram & & \\
< 1 tahun & 60 & 26 \\
1 - 2 tahun & 113 & 48,9 \\
2 - 4 tahun & 45 & 19,5 \\
$>4$ tahun & 13 & 5,6 \\
Total & 231 & 100 \\
Jumlah Following & & \\
$\leq 500$ akun & 188 & 81,4 \\
501 - 1000 akun & 43 & 18,6 \\
Total & 231 & 100
\end{tabular}

\begin{tabular}{|c|c|c|}
\hline \multirow{2}{*}{\multicolumn{3}{|c|}{ Jumlah Followers }} \\
\hline & & \\
\hline$\leq 500$ akun & 144 & 62,3 \\
\hline $501-1000$ akun & 67 & 29 \\
\hline $1001-1500$ akun & 12 & 5,2 \\
\hline$>1500$ akun & 8 & 3,5 \\
\hline Total & 231 & 100 \\
\hline Jumlah Online shop yang di Foll & & \\
\hline 1 - 5 online shop & 104 & 45 \\
\hline 6 - 10 online shop & 75 & 32,5 \\
\hline 11 - 15 online shop & 20 & 8,7 \\
\hline$>15$ online shop & 32 & 13,9 \\
\hline Total & 231 & 100 \\
\hline Frekuensi Belanja di Online shof & n terak & \\
\hline 1 - 3 kali & 195 & 84,4 \\
\hline $4-6$ kali & 28 & 12,1 \\
\hline 7 - 9 kali & 3 & 1,3 \\
\hline$>9$ kali & 5 & 2,2 \\
\hline Total & 231 & 100 \\
\hline Produk paling sering di beli & & \\
\hline Apparel & 136 & 58,9 \\
\hline Aksesoris & 14 & 6,1 \\
\hline Kosmetik & 35 & 15,2 \\
\hline $\begin{array}{l}\text { Lainnya (Hijab, Tas, Sepatu, } \\
\text { dll) }\end{array}$ & 46 & 19,9 \\
\hline Total & 231 & 100 \\
\hline Asal mengetahui Online shop Fa & & \\
\hline Teman & 134 & 58 \\
\hline Keluarga & 11 & 4,8 \\
\hline Lainnya (Promote, Iklan, & & \\
\hline Explore) & 86 & 37,2 \\
\hline Total & 231 & 100 \\
\hline Frekuensi Belanja di Online shof & & \\
\hline 1 kali & 49 & 21,2 \\
\hline 2 kali & 75 & 32,5 \\
\hline 3 kali & 44 & 19 \\
\hline$>3$ kali & 63 & 27,3 \\
\hline Total & 231 & 100 \\
\hline Pertimbangan dalam memfavorit & ne sho & \\
\hline Harga murah & 86 & 37,2 \\
\hline Respon admin cepat & 47 & 20,3 \\
\hline Visualisasi produk menarik & 77 & 33,3 \\
\hline Lainnya & 21 & 9,1 \\
\hline Total & 231 & 100 \\
\hline
\end{tabular}

\section{Analisis Tabulasi Silang}

Dari 231 data yang diperoleh, selanjutnya akan dilakukan tabulasi silang layer terhadap 3 variabel demografi dan usage responden untuk dapat mengetahui adanya karakteristik tertentu dari responden.

\section{Asal Universitas - Frekuensi Belanja Online - Pengeluaran Belanja Online}

Hasil analisis tabulasi silang menunjukkan bahwa dari seluruh responden yang berasal dari 6 universitas di Surabaya mayoritas berbelanja online pada online shop sebanyak 1 hingga 3 kali dalam jangka waktu 3 bulan terakhir ini. Sedangkan untuk pengeluaran dalam belanja online, mayoritas responden mengeluarkan $\leq$ Rp.300.000 per bulannya. Namun terdapat beberapa mahasiswi yang berasal dari Universitas Airlangga yang memiliki pengeluaran untuk belanja online sejumlah Rp.600.001-Rp.1.000.000 dan lebih dari Rp.1.000.000. Diduga mahasiswi Universitas Airlangga lebih hedonis bila dibandingkan dengan mahasiswi dari universitas lain karena mengalokasikan biaya lebih dari Rp.500.000 per bulan untuk berbelanja online.

\section{Asal Universitas - Frekuensi Belanja Online - Produk}

Berdasarkan hasil analisis tabulasi silang, diketahui bahwa mayoritas responden yang berasal dari 6 universitas di 
Surabaya telah berbelanja sebanyak 1 hingga 3 kali dalam 3 bulan terakhir. Produk yang paling sering dibeli oleh responden berupa apparel, yaitu top, dress, jumpsuit, t-shirt, trouser, jeans, short, maupun skirt, dengan responden terbanyak berasal dari ITS. Sedangkan untuk kategori produk kosmetik, responden terbanyak berasal dari Universitas Airlangga. Hasil ini sesuai dengan persepsi masyarakat yang menyatakan bahwa mahasiswa Universitas Airlangga lebih modis dan peduli pada penampilan apabila dibandingkan dengan responden mahasiswi dari universitas lain.

\section{Asal Universitas - Frekuensi Belanja di Online shop Favorit} Pertimbangan Memfavoritkan Online shop

Hasil menunjukkan bahwa mayoritas responden dari 6 universitas di Surabaya memfavoritkan online shop favoritnya karena pertimbangan harga yang murah, dimana mereka telah berbelanja pada online shop favoritnya sebanyak lebih dari 1 kali. Hal tersebut menunjukkan bahwa harga merupakan salah satu pertimbangan yang menentukan niat beli dan niat beli ulang, yang mana sesuai dengan karakteristik konsumen Indonesia yang price sensitive. Salah satu kelebihan online shop adalah harga yang ditawarkan jauh lebih murah apabila dibandingkan dengan offline store, sehingga banyak menarik konsumen yang menginginkan produk dengan harga yang murah.

\section{Asal Universitas - Jumlah Uang Saku - Pengeluaran Belanja Online}

Mayoritas responden yang berasal dari 6 universitas di Surabaya memiliki uang saku $\leq$ Rp.1.000.000 per bulannya. Dengan uang saku tersebut, mayoritas responden memiliki pengeluaran online untuk belanja online sebesar $\leq$ Rp.300.000, yaitu sebanyak 93 responden. Namun terdapat 4 responden mahasiswi Universitas Negeri Surabaya dan 5 responden mahasiswi Universitas Tujuh Belas Agustus yang memiliki pengeluaran belanja online per bulan sebesar Rp.300.001 hingga Rp.600.000 meskipun memiliki uang saku $\leq$ Rp.1.000.000.

\section{Diskusi}

Berdasarkan hasil analisis deskriptif dan analisis tabulasi silang, didapatkan informasi mengenai frekuensi belanja online responden dari 6 Universitas di Kota Surabaya, dimana mayoritas responden berbelanja sebanyak 1 hingga 3 kali selama 3 bulan terakhir. Responden mahasiswi dari ITS, Universitas Negeri Surabaya, UHT, Universitas Tujug Belas Agustus dan UIN Sunan Ampel cenderung memiliki pengeluaran dibawah Rp.600.000, namun cukup banyak mahasiswi Unair yang memiliki pengeluaran diatas Rp.600.000 per bulannya yang menunjukkan gaya hidup konsumtif dan hedonis dalam berbelanja online. Selama berbelanja online dalam waktu 3 bulan terakhir, responden mahasiswi yang berasal dari ITS, Universitas Negeri Surabaya dan Universitas Tujuh Belas Agustus lebih sering berbelanja produk apparel, sedangkan mahasiswi Unair berbelanja produk kosmetik. Hal ini menegaskan persepsi masyarakat dimana kebanyakan dari mahasiswi Universitas Airlangga merupakan mahasiswi yang memperhatikan penampilan.

Sedangkan untuk hubungan antara frekuensi belanja di online shop favorit dan pertimbangan dalam memfavoritkan online shop, lebih dari 50\% responden melakukan pembelian ulang pada online shop favoritnya. Alasan dalam melakukan pembelian ulang tersebut dapat dikarenakan responden merasa puas atas pelayanan, kualitas produk, maupun faktor lain yang diberikan oleh online shop tersebut. Namun yang menjadi faktor utama bagi mayoritas responden dalam memfavoritkan online shop tersebut adalah karena faktor harga yang cenderung lebih murah, sehingga diduga faktor harga merupakan faktor penentu dalam niat beli dan niat beli ulang konsumen untuk berbelanja di online shop favorit responden.

Terakhir, dengan mempertimbangan jumlah uang saku dan pengeluaran belanja online, diduga bahwa jumlah uang saku yang didapat tidak akan menentukan besarnya uang yang digunakan untuk belanja online di online shop, namun hal tersebut bergantung pada sifat masing-masing individu. Dimana terdapat individu yang cenderung hedonis, juga terdapat individu yang bersifat utilitarian yang kemungkinan berbelanja online karena alasan kebutuhan maupun efisiensi. Seperti yang dinyatakan pada hasil analisis tabulasi silang bahwa responden mahasiswi Universitas Negeri Surabaya dan Universitas Tujuh Belas Agustus yang memiliki pengeluaran cukup besar dengan uang saku yang terbatas berkemungkinan bersifat hedonis.

\section{E. Implikasi Manajerial}

Berdasarkan analisis yang telah dilakukan didapat hasil mahasiswi yang menjadi responden dalam penelitian ini adalah mahasiswi kelas menengah, dimana mayoritas responden sangat memperhatikan pengeluaran dalam berbelanja online. Didukung dengan hasil analisis yang menunjukkan bahwa responden mempertimbangan faktor harga sebagai faktor utama dalam memfavoritkan online shop, hal ini dapat menjadi masukan bagi peritel online untuk dapat menerapkan strategi harga serta promosi untuk dapat menarik minat beli konsumen dari kalangan mahasiswi. Dari sisi harga produk yang dijual di online shop, rata-rata produk dijual dengan harga yang lebih murah apabila dibandingkan dengan produk yang dijual pada offline store. Hal tersebut dikarenakan tidak adanya biaya sewa tempat aau lokasi untuk menjual produknya. Harga yang murah dapat menjadi keunggulan karena konsumen Indonesia sendiri cenderung price sensitive.

Terdapat beberapa strategi terkait harga yang dapat diterapkan oleh peritel online yang disesuaikan dengan kondisi dari online shop itu sendiri, seperti strategi loss leader dan price bundling. Bagi online shop ingin meningkatkan jumlah penjualan produk, peritel online dapat menerapkan strategi loss leader dimana terdapat satu produk yang akan dijual dengan harga sangat murah, dengan harapan konsumen akan membeli produk tersebut dan berujung pada impulse buying terhadap produk lain. Sedangkan untuk online shop yang ingin menjual produk yang kurang diminati konsumen atau kurang laku, peritel online dapat menerapkan strategi price bundling, dimana peritel online akan menjual suatu paket produk yang terdiri atas barang yang diminati konsumen sekaligus produk yang kurang diminati dengan harga yang menarik. Sehingga peritel online akan tetap mendapat keuntungan setelah menjual produk yang kurang diminati tersebut. 


\section{KESIMPULAN/RINGKASAN}

Dari penelitian yang telah dilakukan ditemukan bahwa mayoritas responden berusia 21 tahun, dan merupakan mahasiswi kelas menengah dengan uang saku dibawah Rp.1.000.000. Hasil analisis tabulasi silang terhadap variabel demografi dan usage responden menyatakan bahwa responden dengan sifat hedonis dan berpengeluaran besar dalam belanja online adalah minoritas. Sedangkan mayoritas responden memiliki jumlah uang saku yang terbatas yang berujung pada pertimbangan responden untuk mengutamakan harga produk yang murah dalam berbelanja di online shop di Instagram.

Sehingga peritel online harus menyusun strategi yang tepat untuk menarik konsumen mahasiswi dengan uang saku yang terbatas. Terdapat dua strategi yang kiranya akan menarik konsumen mahasiswi yaitu strategi loss leader dan price bundlingm yang dapat diterapkan sesuai dengan kondisi dari masing-masing online shop. Diharapkan dengan diterapkannya strategi tersebut, minat beli konsumen mahasiswi akan meningkat dikarenakan konsumen akan cenderung tertarik dengan adanya promosi maupun penawaran-penawaran produk dengan harga yang murah. Selain itu, strategi tersebut dapat meningkatkan pendapatan serta kredibilitas online shop untuk dapat terus bersaing dan tumbuh dalam bisnis $s$-commerce.

\section{DAFTAR PUSTAKA}

[1] APJII. (2014). Internet. Retrieved from Survei BPS: Jumlah Pengguna Internet Indonesia Tahun 2013 Tembus 71 Juta Orang: http://harianti.com/survei-bps-jumlah-pengguna-internet-indonesiatahun-2013-tembus-71-juta-orang/

[2] Kim, S., \& Park, H. (2013). Effects of various characteristics of social commerce (s-commerce) on consumers' trust and trust performance. International Journal of Information Management, 33(2): 318-332.

[3] Wijaya. (2016). Instagram Users Ages 18-35 in Indonesia Who Follows Digital Retailers on Instagram by Types. https://www.emarketer.com/Article/Instagram-Users-Indonesia-FollowFashion/1013618

[4] Weitz, B. E. (2005). Electronic Retailing. University of Florida, Gainesville, USA, 1-15.

[5] Levy, \& Weitz. (2001). Retailing Management 4th Edition. New York: McGraw Hill, Irwin.

[6] Nanehkaran, Y. A. (2013). An Introduction to Electronic Commerce. International Journal of Scientific and Technology Research, 2(4): 1-4.

[7] Chaffey, D., \& Smith, P. R. (2013). E-marketing Exellence. Planning and optimizing your digital marketing. Abingdon: Routledge.

[8] Turban, E., \& King, D. (2011). Electronic Commerce 2012: Managerial and Social Networks Perspectives (7th Edition). USA: Pearson.

[9] Marsden, P. (2010). Social commerce: Monetizing social media. Syzygy Group.

[10] Park, M.S., Shin, J.-K., \& Ju, Y. (2014). Social networking atmosphere and online retailing. Journal of Global Scholars of Marketing Science, 24(1): 89-106.

[11] Santoso, S., \& Tjiptono, F. (2001). Riset Pemasaran Konsep dan Aplikasi dengan SPSS. Elex Media Komputindo: Jakarta.

[12] Sarwono, J. (2009). Statistik Itu Mudah: Panduan Lengkap untuk Belajar Komputasi Statistik Menggunakan SPSS 16. Yogyakarta: CV. Andi Offset.

[13] Malhotra, N. K., \& Birks, D. F. (2007). Marketing Reseacrh: An Applied Approach (3rd Europe ed). UK: Pearson Education Limited.

[14] Santoso, S., \& Tjiptono, F. (2001). Riset Pemasaran Konsep dan Aplikasi dengan SPSS. Elex Media Komputindo: Jakarta.

[15] Istijanto. (2009). Aplikasi Praktis Riset Pemasaran. Jakarta: Gramedia Pustaka Utama.

[16] Sugiyono. (2014). Metode Penelitian Kuantitatif, Kualitatif, dan Kombinasi (Mix Methods). Bandung: Alfabeta 